\title{
Long-term influence of early human occupations on current forests of the Guiana Shield
}

\author{
Guillaume Odonne, ${ }^{1}$ Martijn van den Bel, ${ }^{2}$ Maxime Burst, ${ }^{3}$ Olivier Brunaux, ${ }^{4}$ Miléna Bruno, ${ }^{1}$ \\ Etienne Dambrine, ${ }^{5}$ Damien Davy, ${ }^{1}$ Mathilde Desprez, ${ }^{6}$ Julien Engel, ${ }^{7,9}$ Bruno Ferry, ${ }^{2}$ Vincent Freycon, ${ }^{8}$ \\ Pierre Grenand, ${ }^{1}$ Sylvie Jérémie, ${ }^{2}$ Mickael Mestre, ${ }^{2}$ Jean-François Molino, ${ }^{9}$ Pascal Petronelli, ${ }^{6}$ \\ Daniel Sabatier, ${ }^{9}$ AND Bruno Hérault iD ${ }^{8,10,11}$ \\ ${ }^{1}$ LEEISA (Laboratoire Ecologie, Evolution, Interactions des Systèmes Amazoniens), CNRS, Université de Guyane, IFREMER, \\ 97300 Cayenne, French Guiana \\ ${ }^{2}$ Institut National de Recherches Archéologiques Préventives, 97300 Cayenne, French Guiana \\ ${ }^{3}$ UMR 1434 Silva, Faculté des Sciences et Technologies, Université de Lorraine-AgroParisTech-INRA, 54506 Vandoeuvre-les-Nancy \\ Cedex, France \\ ${ }^{4}$ ONF-Guyane, Réserve de Montabo, 97307 Cayenne, French Guiana \\ ${ }^{5}$ Univ. Savoie Mont Blanc, INRA, CARRTEL, 74200 Thonon-les-Bains, France \\ ${ }^{6}$ Cirad, UMR Écologie des Forêts de Guyane (AgroParisTech, CNRS, INRA, Université des Antilles, Université de Guyane), 97310 \\ Kourou, France \\ ${ }^{7}$ Department of Biological Sciences, International Center for Tropical Botany, Florida International University, Miami, Florida 33199 \\ USA \\ ${ }^{8}$ Cirad, UR Forests and Societies, Université Montpellier, 34000 Montpellier, France \\ ${ }^{9}$ AMAP, IRD, Cirad, CNRS, INRA, Université de Montpellier, 34000 Montpellier, France \\ ${ }^{10}$ Institut National Polytechnique Félix Houphouet-Boigny (INP-HB), Yamoussoukro, Ivory Coast
}

Citation: Odonne, G., M. van den Bel, M. Burst, O. Brunaux, M. Bruno, E. Dambrine, D. Davy, M. Desprez, J. Engel, B. Ferry, V. Freycon, P. Grenand, S. Jérémie, M. Mestre, J.-F. Molino, P. Petronelli, D. Sabatier, and B. Hérault. 2019. Long-term influence of early human occupations on current forests of the Guiana Shield. Ecology 100(10):e02806. 10.1002/ecy.2806

Abstract. To decipher the long-term influences of pre-Columbian land occupations on contemporary forest structure, diversity, and functioning in Amazonia, most of the previous research focused on the alluvial plains of the major rivers of the Amazon basin. Terra firme, that is, nonflooded forests, particularly from the Guiana Shield, are yet to be explored. In this study, we aim to give new insights into the subtle traces of pre-Columbian influences on present-day forests given the archaeological context of terra firme forests of the Guiana Shield. Following archaeological prospects on 13 sites in French Guiana, we carried out forest inventories inside and outside archaeological sites and assessed the potential pre-Columbian use of the sampled tree species using an original ethnobotanical database of the Guiana Shield region. Aboveground biomass ( 320 and $380 \mathrm{~T} / \mathrm{ha}$, respectively), basal area (25-30 and $30-35 \mathrm{~m}^{2} / \mathrm{ha}$, respectively), and tree density (550 and $700 \mathrm{stem} / \mathrm{ha}$, respectively) were all significantly lower on anthropized plots (As) than on nonanthropized plots (NAs). Ancient human presence shaped the species composition of the sampled forests with Arecaceae, Burseraceae, and Lauraceae significantly more frequent in As and Annonaceae and Lecythidaceae more frequent in NAs. Although alpha diversity was not different between As and NAs, the presence of pre-Columbian sites enhances significantly the forest beta diversity at the landscape level. Finally, trees with edible fruits are positively associated with pre-Columbian sites, whereas trees used for construction or for their bark are negatively associated with pre-Columbian sites. Half a millennium after their abandonment, former occupied places from the inner Guiana Shield still bear noticeable differences with nonanthropized places. Considering the lack of data concerning archaeology of terra firme Amazonian forests, our results suggest that pre-Columbian influences on the structure (lower current biomass), diversity (higher beta diversity), and composition (linked to the past human tree uses) of current Amazonian forests might be more important than previously thought.

Key words: Amazonian forest; archaeology; ethnobotany; Guiana Shield; historical ecology; preColumbian settlements; ring-ditched hills.

Manuscript received 16 November 2018; revised 29 May 2019; accepted 13 June 2019. Corresponding Editor: Richard T. Corlett.

${ }^{11}$ Corresponding Author. E-mail: bruno.herault@cirad.fr

\section{INTRODUCTION}

A growing body of archaeological and pedological evidence, accumulated since the 1990s, suggests that Amazonian rainforests might have been much more densely 
occupied and intensely modified by Amerindian societies before the First Contact than previously thought (Heckenberger et al. 2003, 2008, Clement et al. 2015). By challenging the common idea of "pristine" tropical forests (Bahuchet et al. 2000, Barlow et al. 2012), these discoveries have stimulated tropical forest scientists to consider pre-Columbian human activities as one of the potential factors shaping the current biodiversity, structure, and functioning of Amazonian rainforests (Clement et al. 2015). Throughout the Amazonian basin, several studies in historical ecology have highlighted the importance of human activities in the composition and structure of modern forests. This long-lasting impact was first detected in the structure and chemistry of soils (Sombroek 1966, Smith 1980, Schmidt and Heckenberger 2009, Arroyo-Kalin 2010, Schmidt 2010) with Anthropogenic Dark Earths (ADE), that is, black, C-, $\mathrm{P}$ - and N-enriched, anthropogenic soils called Terra preta do Indio in Brazilian Portuguese. Floristic composition has also been directly impacted (Heckenberger et al. 2007, Levis et al. 2012, 2017) with the possible dissemination of many wild or incipiently domesticated species, such as Bertholletia excelsa, the Brazil nut tree (Clement 1999, Shepard and Ramirez 2011), and many palms, as well as domesticated crop plants (Balée 2013, McMichael et al. 2015, Piperno et al. 2015). Lastly, Amazonian landscapes, with their entanglements of forests and savannas, also generally reflect the presence of humans with large earthworks detectable from the sky such as geoglyphs (Schaan 2011, Stahl 2015, Watling et al. 2017a, Souza et al. 2018), residential mounds and causeways (Erickson 2000), and cities (Heckenberger et al. 2008). These impacts have mainly been shown for the alluvial plains of the Xingu, the Tapajos, the Madeira, and Acre state. Traces of past human activity are nonetheless numerous in the Guiana Shield area, differing from southern Amazonia by its climate, substrate, and biogeographical history. Archaeological artefacts are frequent from the coastal area to the southern border of the Guiana Shield, and anthropogenic landscapes are still present. On the coastal plains savannas, raised fields are amongst the most amazing structures seen in tropical ecosystems (Rostain 2008, 2010, 2012). It is hypothesized that they originate from abandoned Amerindian fields and subsequently engendered self-organizing processes driven by ecosystem engineers (ants, termites, earthworms, and woody plants) that have preserved the physical vestiges of these fields up to the present day (McKey et al. 2010). Further south, in the forest-covered part of the Guiana Shield, hills topped by ring-ditches or simply crossed by anthropogenic ditches (Mestre et al. 2008, Mestre 2013) can be observed. These structures testify to the major earthworks made by preColumbian Amerindians with many sites exceeding several hectares in area. Few data exist about these sites in the Guiana Shield, but a sort of parallel can be made with the geoglyphs observed in the Brazilian state of Acre (Saunaluoma and Schaan 2012, Watling et al. 2017a). But most earthworks of the Guiana Shield are still covered by dense and so-called "mature" forests, whereas Acre structures were observed after deforestation. As highlighted by the recent papers by Levis et al. $(2012,2017)$ and Watling et al. $(2017 a)$, the influence of pre-Columbian occupation on terra firme forest composition and diversity is hotly debated everywhere in Amazonia (Bush et al. 2015, Piperno et al. 2015, 2017, Watling et al. 2017b), tipping in favor of an enrichment of useful species by previous occupants (Junqueira et al. 2011). For the Guiana Shield, the results obtained by Levis et al. (2017) suggest a weak influence of preColumbian occupation on forests. However, by focusing only on some edible domesticated species that are widely consumed throughout Amazonia, this study ignores nondomesticated species and those that are consumed in certain regions only. Second, past human influences must have been much more diverse than just the favoring of edibles and large seed trees. Over generations, the falling of trees to build houses or using wood or bark for crafts and medicine might have depleted the surrounding populations of the species so used for a long time. The sparsity of archaeological data available for the interior of the Guiana Shield might also lead to a misunderstanding of the regional situation.

In this paper, we aim to give new insights into the archaeological context of terra firme forests of the Guiana Shield, and to help decipher the subtle traces of preColumbian influences on present-day forests. Moreover, the unique context in French Guiana of massive earthworks and "preserved" long-lasting forests (Barthe et al. 2017) might be a perfect combination to improve our understanding of long-term human-forest interactions in Amazonia. Hypothesizing that French Guianese earthworks have probably been subject to long-term occupation, either ceremonial, housing, or public gathering, the vegetation growing on them should have been impacted by a variety of uses, and this may have longterm aftereffects on their present-day structure and composition. Comparing these anthropized areas to areas with no evidence of past human presence in order to test the Levis et al. (2017) hypothesis is a preliminary step. In a second step, we interpret the differences observed assuming that different uses of biodiversity, such as consumption of fruit gathered from the wild and prepared at a residential site, peeling off bark for medicinal purposes, or felling of trees to make house posts, had contrasted impacts on the surrounding vegetation. To reach this objective, a nearly exhaustive historical compilation of ethnobotanical uses in the region was amassed. It concerns five of the Amerindian groups of the Guianas belonging to the three linguistic families represented today in the area: Carib, Arawak, and Tupi-Guarani.

\section{Methods}

This study involved 13 forest permanent plots, including 12 from the Guyafor (Grau et al. 2017) network 
distributed throughout the northern two-thirds of French Guiana (Fig. 1). The Guyafor network has been designed to assess the main climate and geological drivers of the old-growth forests in northern French Guiana. We selected all permanent plots (Table 1, SUPMAT 1, 2, 3) with high-level of botanical determination that respect the international standards (Chave et al. 2019), most of them belonging also to the Guyadiv network (http://atdnmorphospecies.myspecies.info/node/ 781). All individual trees $(\geq 10 \mathrm{~cm}$ in diameter at breast height) present in the plots were marked, mapped, and measured. Common species were identified in the field, and vouchers collected on all other species were identified and deposited at Herbier IRD de Guyane (CAY). The total data set included 7,820 trees. Individuals determined to the genus level only represent $4.63 \%$ of all individuals.

\section{Archaeological research}

The surface of each plot was surveyed by archaeologists. Evidence for pre-Columbian human occupations (such as artifacts, dark soils, earthworks) was searched for in the field, by superficial prospection of the ground surface while walking and carefully examining soil heaps expelled from burrows and mounds resulting from unrooted trees. Exploratory test pits were also dug to confirm surface observations and to establish soil profiles. This allowed classifying plots as either anthropized (A) or less- or nonanthropized plot (NA). In fact, site detection in the Guianas can often be accomplished by means of a "simple" pedestrian survey, notably on the Precambrian Shield. A trained eye can spot ceramic shards or lithic debris located between the roots of fallen trees and around holes made by agoutis or armadillos. Charcoals found in anthropized plots were radiocarbon dated after calibration using OxCal ver. 3.10. (Appendix S1). Details (type of occupations, site descriptions, dates) on the As and NAs can be found in supplementary materials (Appendices S2 and S3).

Compared to the coastal zone, the area of high forest on terra firme where the studied plots are located was poorly studied by archaeologists working in the Guiana Shield, because it is isolated and difficult to access. All the plots are within $80 \mathrm{~km}$ of modern Amerindian villages. The selected Amerindian groups for the

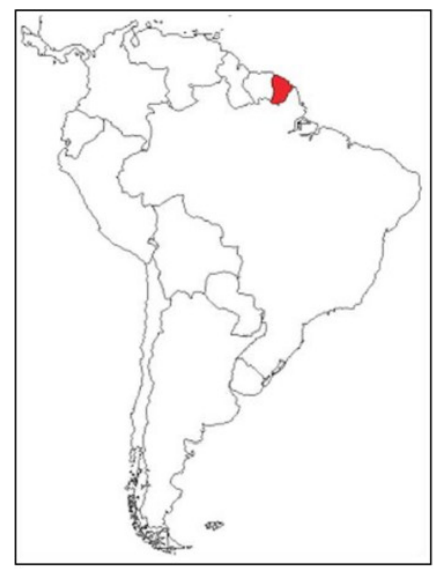

\section{Legend}

$\checkmark$ Anthropized plots

- Nonanthropized plots

- Main rivers and lakes

* Archaeological sites
0

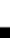

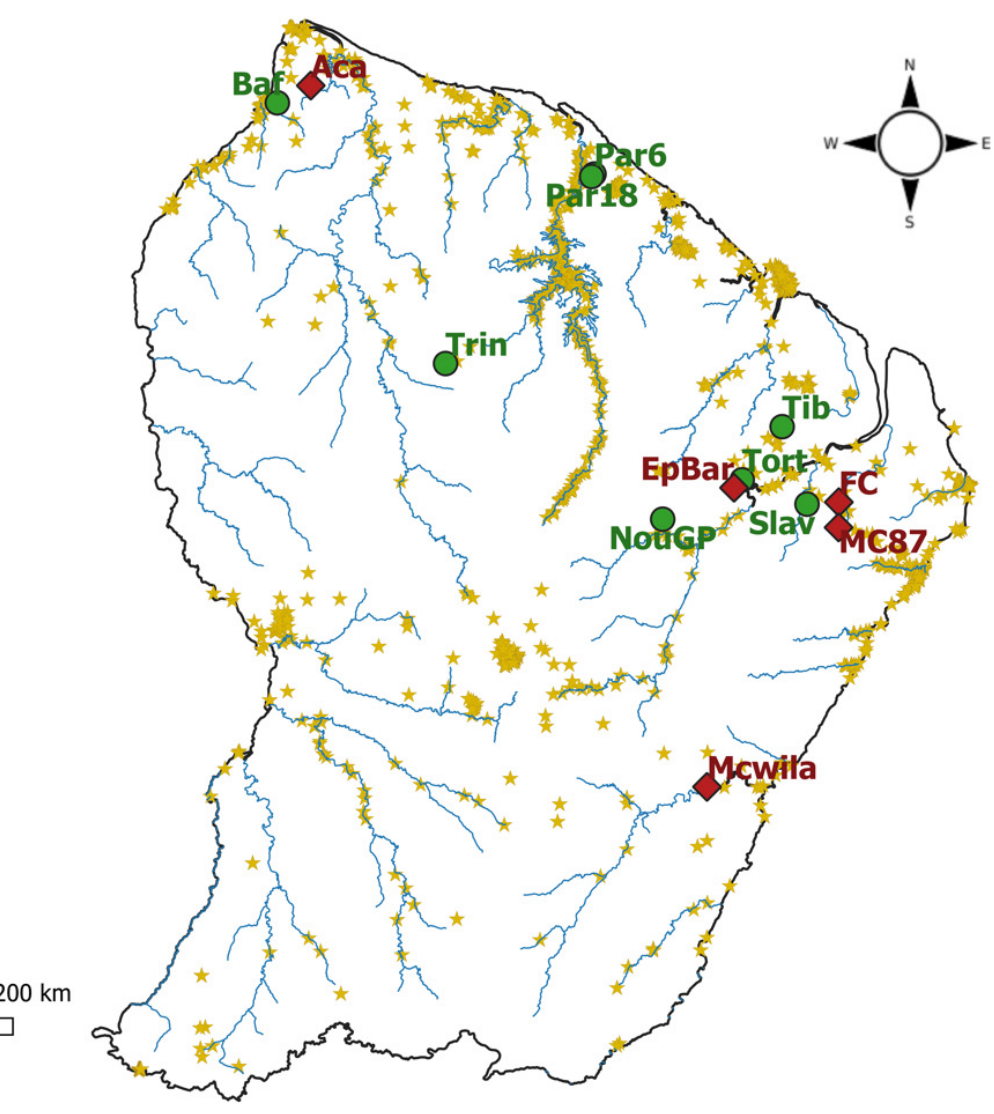

$200 \mathrm{~km}$

FIG. 1. Overview of the studied area and the anthropized (red diamonds) and nonanthropized (green circles) plots. Main rivers and archeological sites (listed in the Patriarche database of the Direction régionale des affaires culturelles-Service regional d'Archéologie of French Guiana) are reported. 
TABLE 1. Overview of the sampled plots in French Guiana, botanical description, plot area, and occupation dates.

\begin{tabular}{|c|c|c|c|c|c|c|c|c|c|c|c|c|c|}
\hline $\begin{array}{l}\text { Plot } \\
\text { name }\end{array}$ & $\begin{array}{l}N \\
\text { trees }\end{array}$ & $\begin{array}{c}N \\
\text { family }\end{array}$ & $\begin{array}{c}N \\
\text { genus }\end{array}$ & $\begin{array}{c}N \\
\text { species }\end{array}$ & $\begin{array}{c}\% \\
\text { Determination }\end{array}$ & $\begin{array}{c}\text { Area } \\
\text { (ha) }\end{array}$ & $\begin{array}{l}\text { Altitude } \\
(\mathrm{m})\end{array}$ & $\begin{array}{c}\text { Rainfall } \\
(\mathrm{mm})\end{array}$ & Topography & $\begin{array}{l}\text { Soil } \\
\text { type }\end{array}$ & $\begin{array}{l}\text { Distance } \\
\text { to river } \\
\text { (m) }\end{array}$ & $\begin{array}{l}\text { Site } \\
\text { type }\end{array}$ & $\begin{array}{l}\text { Dating } \\
\text { (AD) }\end{array}$ \\
\hline Aca & 454 & 42 & 93 & 148 & 95.59 & 1.00 & 45 & 3300 & Hilltop & DVD & 2931 & $\mathrm{~A}$ & $1100-1600$ \\
\hline Baf & 756 & 39 & 106 & 183 & 93.65 & 1.00 & 33 & 3100 & Hilltop & DVD/Alt & 1411 & NA & - \\
\hline EpBar & 415 & 39 & 100 & 164 & 98.80 & 0.80 & 146 & 4500 & Hilltop & DVD & 4940 & A & 1000 \\
\hline $\mathrm{FC}$ & 515 & 44 & 106 & 194 & 98.83 & 1.14 & 41 & 4500 & Hilltop & DVD & 1298 & A & $700-1400$ \\
\hline MC87 & 821 & 45 & 127 & 274 & 98.78 & 1.83 & 84 & 4300 & Hilltop & DVD & 3126 & A & $400-1300$ \\
\hline Mcwila & 654 & 41 & 103 & 173 & 98.32 & 1.17 & 100 & 2900 & - & - & 1362 & A & NA \\
\hline NouGP & 536 & 43 & 104 & 169 & 89.37 & 1.00 & 108 & 3900 & Slope & DVD & 5175 & NA & - \\
\hline Par18 & 499 & 42 & 103 & 158 & 96.39 & 1.00 & 31 & 4100 & Slope & SLD & 3751 & NA & - \\
\hline Par6 & 964 & 41 & 106 & 189 & 94.19 & 1.56 & 42 & 4100 & Slope & $\begin{array}{l}\text { Alt/SLD/ } \\
\text { DhS }\end{array}$ & 4756 & NA & - \\
\hline Slav & 620 & 44 & 106 & 200 & 88.23 & 1.00 & 87 & 4500 & Hilltop & DVD & 2549 & NA & - \\
\hline Tib & 440 & 41 & 114 & 176 & 95.00 & 1.00 & 82 & 5100 & Hilltop & DVD/Alt & 12346 & NA & - \\
\hline Tort & 496 & 46 & 122 & 193 & 94.15 & 1.00 & 170 & 4500 & Hilltop & DVD & 4012 & NA & - \\
\hline Trin & 650 & 40 & 112 & 187 & 98.92 & 1.00 & 146 & 3500 & Hilltop & DVD & 8996 & NA & - \\
\hline
\end{tabular}

Note: Soil type was associated to drainage conditions following Sabatier et al. (1997): deep vertical drainage (DVD), vertical drainage until 100-cm depth (Alt), superficial lateral drainage (SLD), and hydromorphic downhill system (DhS).

ethnobotanical study are distributed in all habitats, and used to forage in all forest types. Although most of the present archaeological knowledge originates from discrete reports, about 1,300 geolocated references, including archaeological sites as much as single objects, were recorded in the database of the French Guiana archaeological service (Fig. 1). The studied archaeological sites yielded stone and ceramic material, but little can be said about cultural affiliation, even compared to the coastal zone. We might, however, discern various sites such as (1) open-air sites with brown soils and few material (Aca) and (2) ditched sites with (a) either a short ditch closing a hillock $(E p B a)$ or (b) encircling a hilltop (MC87, FC, and MCwila). This second type of site may have brown and dark-colored soils. Sites are generally situated on hilltops and usually are restricted to the summit of a hillock or restricted to a part of a plateau.

\section{Effect of past anthropization on current tree communities}

The effect of past anthropization was first investigated on standard forest structure descriptors: tree density, quadratic diameter, basal area and aboveground biomass calculated with the BIOMASS package (RéjouMéchain et al. 2017). Differences between As and NAs were assessed with Wilcoxon-Mann-Whitney nonparametric tests.

Botanical composition among plots was first compared with a detrended correspondence factor analysis (DCA) under vegan R package (Oksanen et al. 2015). Then, any past anthropization effect on the 20 most abundant families was tested with Wilcoxon-MannWhitney test. Finally, we looked for indicator species, keeping in mind that correlation can be either direct (managed species) or indirect (consequence of a specific pattern of recolonization after occupation), and positive (species for which human occupation is favorable) or negative (species for which past human occupation is detrimental). We used the Dufrêne and Legendre (1997) methodology implemented with the package indicspecies (De Caceres et al. 2012).

Functional composition was also assessed to avoid local botanical variations in tree assemblages that are of little importance for forest functioning (Hérault and Piponiot 2018). The four chosen functional traits represent key dimensions of the tree functional strategy response to disturbance (Hérault et al. 2010, Flores et al. 2014, Hogan et al. 2018): wood density, seed mass, specific leaf area, and maximum diameter from a regional trait database (Baraloto et al. 2010a, Hérault et al. 2011). The community weighted means of these functional traits were calculated. Differences between As and NAs were assessed with Wilcoxon-Mann-Whitney nonparametric tests.

Neutral and functional Shannon alpha and beta diversities were calculated for each plot using the "entropart" package (Marcon and Herault 2015a, b). (1) For alpha diversity, we used the function AlphaDiversity() that calculates the reduced-bias total alpha diversity of each community without (neutral diversity) and with a functional tree (functional diversity). The functional tree was obtained using the following procedure (Hérault 2007, Hérault and Honnay 2007). First, a similarity matrix between species was calculated based on the four chosen (see above) functional traits and using Gower's similarity coefficient, and the resulting matrix was used to cluster the species using Ward's method. The resulting cluster was then used in the AlphaDiversity() function. Differences in neutral and functional Shannon alpha between As and NAs were tested using WilcoxonMann-Whitney tests. (2) We assessed beta diversity using the following procedure. From the 13 investigated sites, we randomly sampled assemblages of four sites and calculated (1) their beta diversity and (2) the 
proportion of anthropized plots in the assemblages $(0$, $25,50,75$, or $100 \%$ ). We repeated the procedure 200 times per proportion of anthropized plots. Then, we compared beta-diversity levels between the different proportion of anthropized plots and tested the hypothesis that the presence of anthropized forests in the landscape increases the overall beta diversity with a Spearman's rank correlation test.

\section{Ethnobotanical analyses}

Data collection. - Because of the absence of an existing database on the uses of plants in forests of the Guiana Shield, a compilation of contemporary ethnobotanical surveys was conducted. First, species represented by only one or two individuals (6.6\% of all individuals) were excluded, considering that rare species are less known and therefore more likely to be misidentified. A comprehensive ethnobotanical database was then created considering the available information of the 457 remaining species present in all sampled plots.

Although contemporary uses probably differ in some ways from past uses, the compilation of available information for present-day Amerindian groups (Palikur, Arawak, Wayãpi, Teko, and Kali'na) belonging to the three linguistic families in French Guiana (Arawak, Tupi-Guarani, and Karib) was thought to be the best proxy for potential pre-Columbian uses. The choice of the data sets to be compiled was driven by three selection criteria: (1) geographical coherence (inclusion of the main cultural groups of the Guiana Shield and their knowledge of tree species in the region), (2) completeness (high number of taxa recorded), and (3) quality (reliable methodologies). Most of the information is comprised of unpublished or sparsely published data from previous works, with the exception of those available for the Arawak and Kali'na ethnic groups.

All the ethnobotanical data were obtained before adoption of the ABS laws in French Guiana, and no written informed consent document was signed between traditional authorities and the researchers, except for the Teko, with whom a document was signed between the Chief and the concerned investigators in July 2013. The other works were concluded under the verbal agreement of authorities during long years of continuous fieldwork.

Palikur and Arawak belong to the Arawak linguistic family, Wayãpi and Teko to the Tupi-Guarani linguistic family, and Kali'na to the Karib linguistic family. These three families are among the most important of those spoken in the Eastern Amazonian lowlands. Five Amerindian groups now occupy different ecosystems, ranging from estuaries and coastal savannahs to terra firme forests in French Guiana. Data were obtained as follows:

- Palikur ethnobotanical data were accumulated during 34 yr (1972-2012) of research with a dozen key knowledge holders of Palikur communities from French Guiana. The knowledge was recorded during several research projects associating Palikur collaborators, through ethnobotanical walks and plot inventories, around Saint-Georges de l'Oyapock and Regina villages. Some published works include Grenand et al. (2004) and Ogeron et al. (2018).

- Wayãpi ethnobotanical data were collected over 38 yr of research with some 20 key knowledge holders of Wayãpi communities of French Guiana. The knowledge was recorded through several research projects associating Wayãpi collaborators. Methods used were ethnobotanical walks and plot inventories, around Trois-Sauts and Camopi villages. Some published works include Grenand (1980) and Grenand et al. (2004).

- Kali'na ethnobotanical data were compiled integrating bibliographic data (Aublet 1775, Ahlbrinck 1931, Kloos 1971, van Andel 2000, ONF, 2004) and field data (ethnobotanical studies conducted between 2006 and 2008). The only field data were recorded during a 2-yr-long research program, mainly based on ethnobotanical walks with four collaborators around AwalaYalimapo village, and restituted to the Kali'na in 2008.

- Teko ethnobotanical data were recorded from 2013 to 2015 through ethnobotanical walks and repeated passages in the sampled plots, located around Camopi village, with seven informants.

- Arawak ethnobotanical bibliographical data were obtained from Arawak populations in northwestern Guyana (van Andel 2000). According to the author, they were completed through repeated passages in seven plots of one hectare and through ethnobotanical walks.

Traditional uses. - Traditional use categories were compiled following the methodology developed in previous studies (Prance et al. 1987, Grenand 1992, Balée 1994, Chazdon and Coe 1999): "construction," "firewood," "human food," "medicine and magic," and "arts and crafts." A species can enter from zero to five categories. The "construction" category includes species used for posts and other structural elements of buildings. Species of large diameter ( $>50-\mathrm{cm}$ diameter at breast height) used now as timber in the Guiana Shield (Fargeon et al. 2016, Piponiot et al. 2018, 2019) and requiring the use of a chainsaw, were removed. Without metal, these species were significantly less used by pre-Columbian populations than in the present day. Species requiring no mechanical process for preparation of their wood (round wood) were retained for analysis. The "firewood" category was intentionally kept apart from construction woods, as contemporary Amerindians often collect firewood dry, leading to a distinct pattern of collecting. The "human food" category encompasses main and secondary foods, as well as plants used for seasoning, excluding plants used as fishing/hunting baits. The "medicinal and magic" category includes medicinal plants, poisons, body dyes, and plants used for hygiene. 
The category "arts and crafts" includes plants used to make musical instruments, weapons, games, tools, paddles, pirogues, and artisanal dyes.

Plant parts. - The second system of classification used is that of the "plant parts" categories, as the use categories are not necessarily the best proxy to determine the impacts of traditional uses on the resource (felling of a tree to make a house has evident consequences, but taking a piece of bark from a tree for medicine might provoke a defensive reaction paradoxically increasing the tree's probability of survival). We judged that making categories of both uses and parts at the same time would split the data set into too many subtle categories. Plant parts categories we retained are "bark," "wood and stems," "seeds and fruits," "leaves and flowers," "exudates," and "underground organs."

\section{Statistical analyses}

Synthetic use values were established separately for traditional uses and for plant parts, in a binary way, based on the assumption that although contemporary uses may reflect past uses, the frequency of contemporary use does not necessarily reflect the frequency of preColumbian use. Each species cited at least once for a given contemporary use was thus given a use value of 1 for the corresponding category (traditional uses or plant parts), regardless of how many present-day groups use it. The major advantage of the nonquantitative approach is to avoid the bias induced by the variable presence of a species in the territories of different ethnic groups within the region, and the methodological differences among the ethnobotanical studies, leading to imbalances between cultural groups.

To compare the distribution of use values and plant parts (both expressed as a $\%$ of individual trees that may be used in a given plot) between As and NAs, WilcoxonMann-Whitney tests were used.

\section{RESUlTS}

\section{Forest structure, composition and diversity}

Forest structure was significantly different between As and NAs (Fig. 2). While As had a median aboveground biomass of about $320 \mathrm{~T} / \mathrm{ha}$, the aboveground biomass of the NAs control plots was $380 \mathrm{~T} / \mathrm{ha}$ on average. The same applied for basal area and tree density with, respectively, $25-30 \mathrm{~m}^{2} / \mathrm{ha}$ and less than $550 \mathrm{stem} / \mathrm{ha}$ for As and $30-35 \mathrm{~m}^{2} / \mathrm{ha}$ and up to $750 \mathrm{stem} / \mathrm{ha}$ in NAs. Quadratic diameter only was similar, around $28 \mathrm{~cm}$, in As and NAs.

The forest composition of As, as assessed with the DCA, was very well separated from NA along the first axis (Fig. 3) that represents 35\% of the observed variation in species composition. Past human occupation is the main source of differences in species composition among our sampled plots and this is reflected in the detailed analysis of the 20 most abundant families that were unequally distributed between As and NAs (Appendix S4: Fig. S1; Appendix S5: Table S1). Five families had clear patterns of segregation $(P<0.05)$. These are Arecaceae (e.g., Astrocaryum sciophylum, Oenocarpus bacaba), Burseraceae, and Lauraceae, which are significantly more frequent in As; and Annonaceae
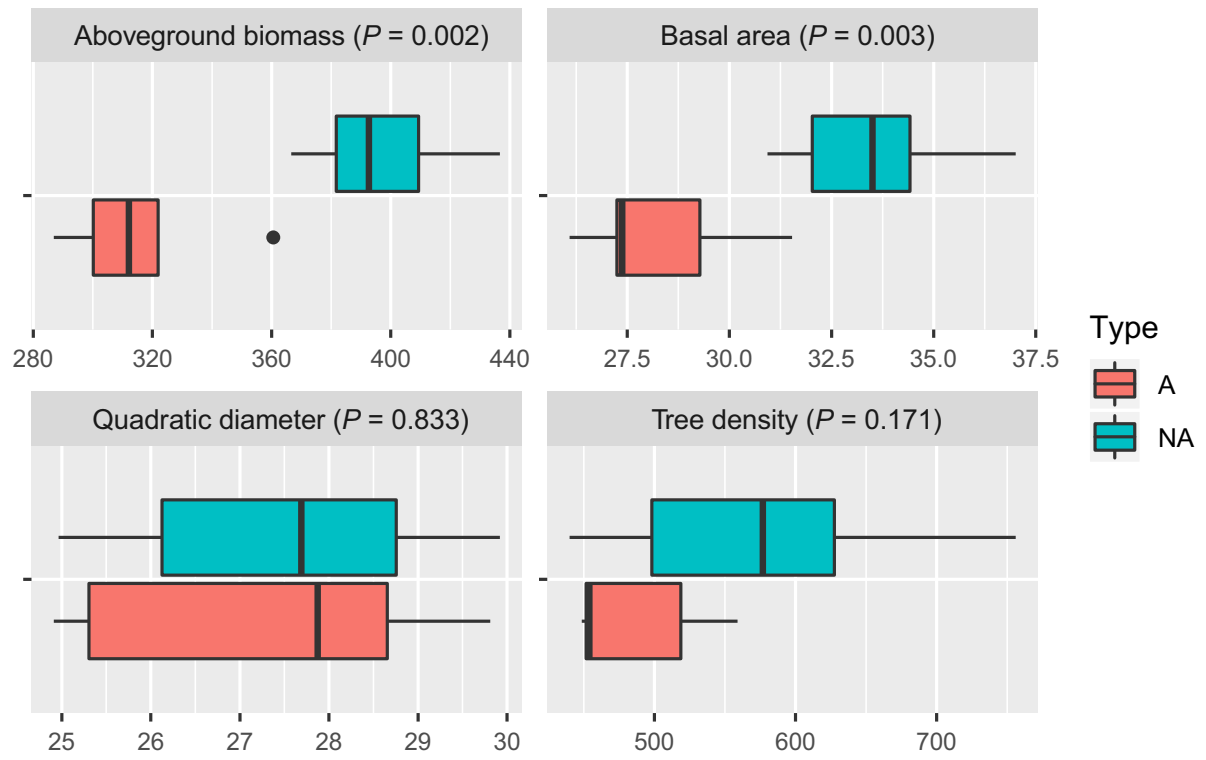

FIG. 2. Comparison of forest structure descriptors (aboveground biomass in $\mathrm{T} / \mathrm{ha}$, basal area in $\mathrm{m}^{2} /$ ha, quadratic diameter in $\mathrm{cm}$ and tree density in stem/ha) between anthropized (A) and nonanthropized (NA) plots. $P$ values from Mann-Whitney nonparametric tests. 


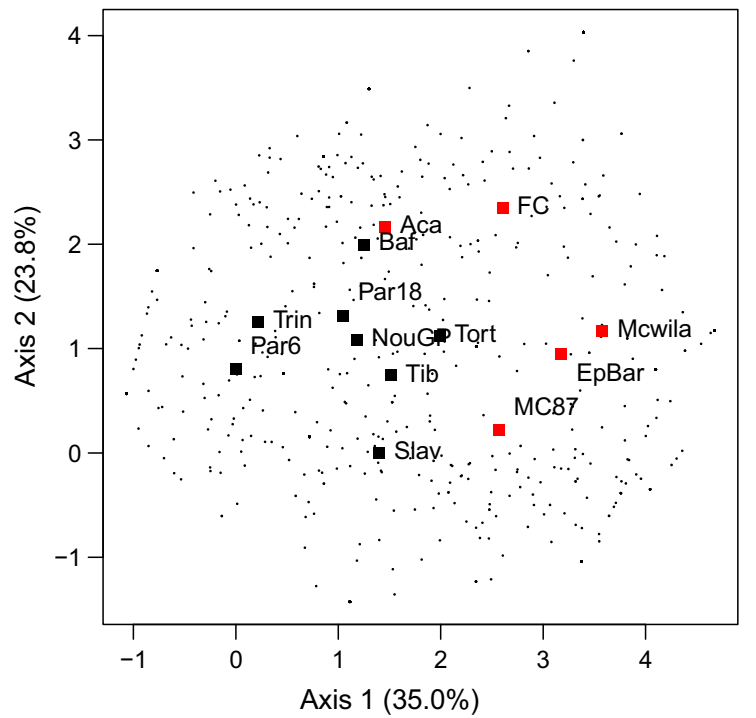

FIG. 3. Anthropization is the main factor driving the forest community composition. Detrended correspondence analysis with species as small dots and large dots as sampled sites, either As (black) or NAs (red).

and Lecythidaceae (e.g., Couratari multiflora, Lecythis persistens), which are associated with NAs.

Among the four investigated functional traits (Fig. 4), tree height only was significantly different, although marginally, between As (32.5 $\mathrm{m}$ on average) and NAs $(33.5 \mathrm{~m})$. However, even if not significant, seed mass and wood density were lower in As than in NAs, and
SLA averaged $31-32 \mathrm{~cm}^{2} / \mathrm{g}$ in As and less than $30 \mathrm{~cm}^{2} / \mathrm{g}$ in NAs.

Both neutral and functional alpha diversities did not differ between anthropized (A) and nonanthropized (NA) plots (Appendix S6: Fig. S1), even if the functional diversity tended to be higher in A plots. Regarding beta diversity, (1) the value of the neutral beta diversity significantly increased with the proportion of anthropized (A) plots in the simulated assemblages (Spearman's rank correlation test, $-=0.31, P<0.001)$ but saturated for proportions above $50 \%$ (Fig. 5); and (2) the value of the functional beta diversity showed no significant trend (Spearman's rank correlation test, rho $=-0.06$, $P>0.05)$, but a hump-shaped pattern with the proportion of anthropized (A) plots in the simulated assemblages (Fig. 5).

\section{Ethnobotanical results}

On average, among the different species, 47.7\% (218/ $457)$ are used for crafts, $32.8 \%(150 / 457)$ as building material, $27.8 \%$ (127/457) for medicinal/magical use, $27.6 \%$ (126/457) are used as firewood, and 26.7\% (122) produce plant parts edible for human food. Considering the parts used, the most frequent use is of the wood (58.9\%; 269/ 457). Seeds and/or fruits are used for $30.6 \%$ of the species (140/457), bark for $25.2 \%$ (115/457), exudates for $10.3 \%$ (47/457), leaves and/or flowers for $6.8 \%(31 / 457)$, and roots or other underground parts for $0.9 \%$ (4/457).

Trees used as human food were significantly more abundant $(P=0.03)$ in As than in NAs (Fig. 6). No conclusion can be drawn for species in the "firewood,"
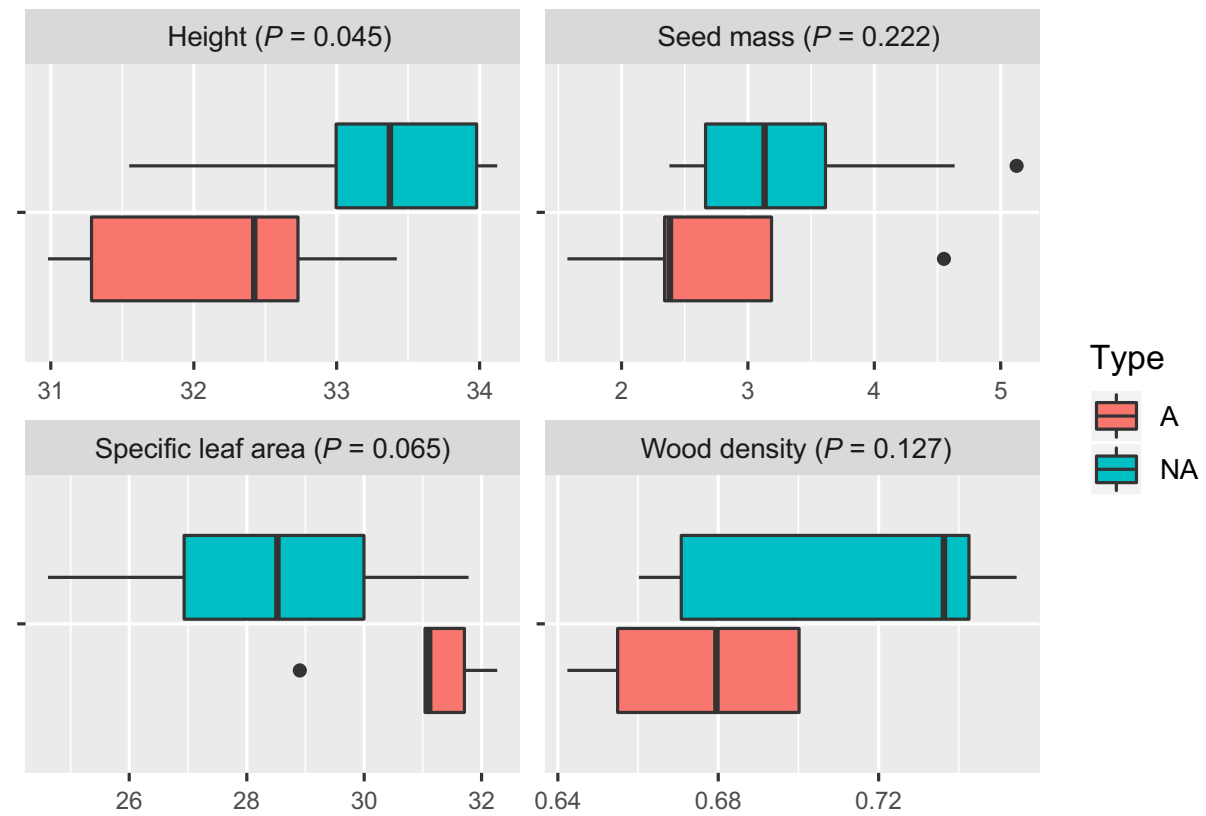

FIG. 4. Comparison of functional trait community weighted means (height in $\mathrm{m}$, seed mass in g, specific leaf area in $\mathrm{cm}^{2} / \mathrm{g}$, and wood density in $\mathrm{g} / \mathrm{cm}^{3}$ ) between anthropized (A) and nonanthropized (NA) plots. $P$ values from Mann-Whitney nonparametric tests. 


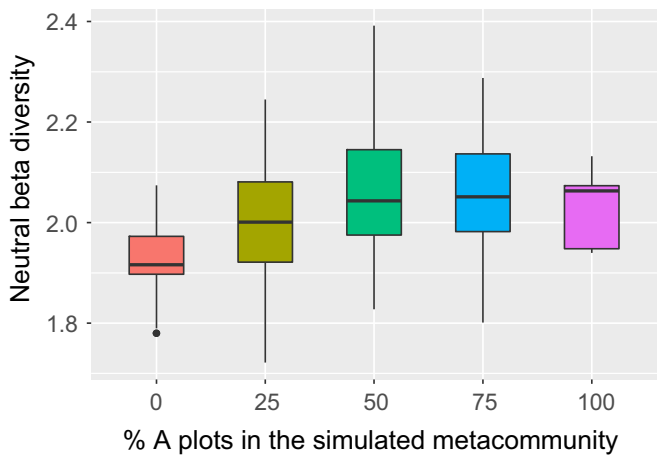

(a)

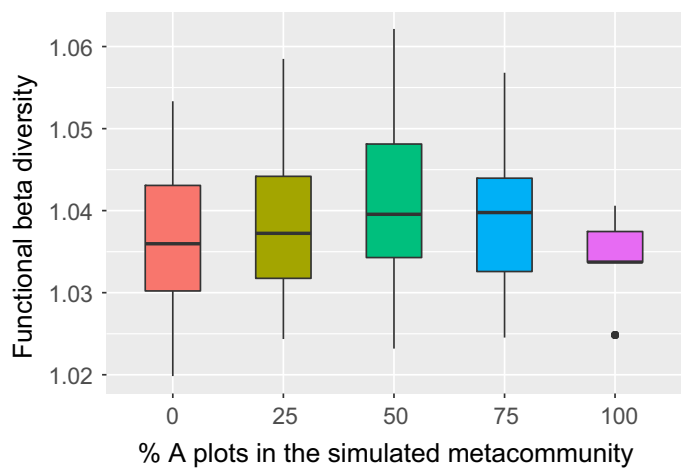

(b)

FIG. 5. Comparison of neutral (a) and functional (b) betadiversity levels between different proportion of anthropized plots in randomly sampled plot assemblages.

"medicine and magic," and "arts and crafts" categories, owing to their high $P$ values. Last, species used in construction are more often present $(P=0.045)$ in nonanthropized plots than in As.

Plants with useful seeds and fruits $(P=0.045)$, exudates $(P=0.171)$, leaves and flowers $(P=0.171)$, and underground organs $(P=0.241)$ were, at diverse scales, more abundant on As than on NAs (Fig. 7). The most striking difference concerned species with useful seeds and fruits. Conversely, an increase in the abundance of plants used for their bark $(P=0.045)$ was observed for the NAs, whereas no trend can be determined for the species used for their wood and stems $(P=0.435)$, but the variation in the proportion of trees used for wood among NA plots seems higher than among A plots.

\section{DisCusSION}

In this paper, we aimed to help decipher the subtle traces of pre-Columbian influences on the structure, diversity, and composition of tree communities in present-day forests of the Guiana Shield. We found that (1) aboveground biomass, basal area, and tree density were all significantly lower on pre-Columbian sites; (2) pre-Columbian presence shaped the current variation in species composition with 5 among the 20 most abundant

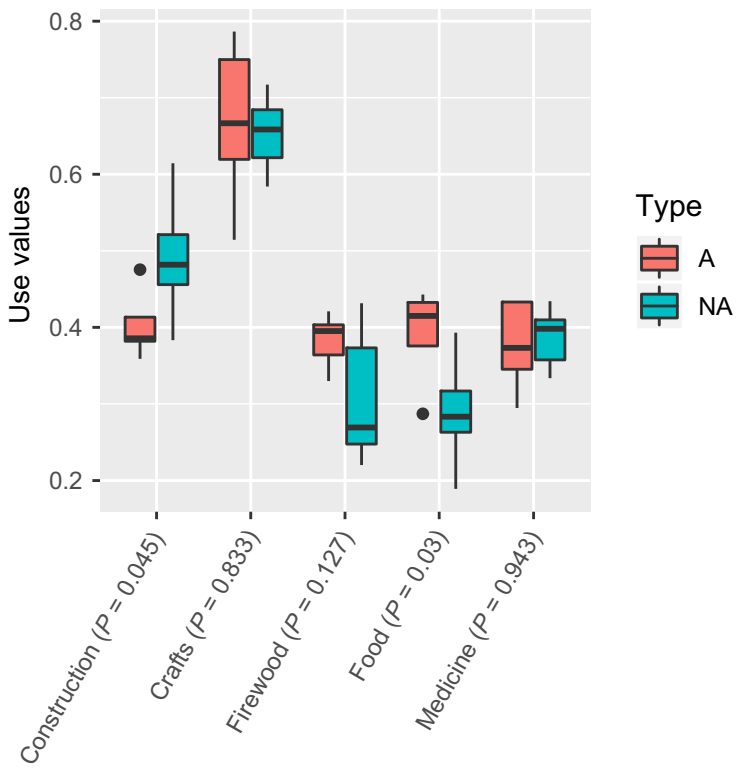

FIG. 6. Comparison of use values ( $\%$ of trees per plot that can be used for a given use) between anthropized (A) and nonanthropized (NA) plots. $P$ values from Mann-Whitney nonparametric tests.

families displaying a clear pattern of segregation (Arecaceae, Burseraceae, and Lauraceae associated to preColumbian presence and Annonaceae and Lecythidaceae associated to pre-Columbian absence); (3) the presence of pre-Columbian sites strongly enhances the forest beta diversity at the landscape level; and (4) on pre-Columbian sites trees with edible fruits are more frequent and trees used for construction are less frequent.

\section{Forest structure - a lower biomass and tree density on pre-Columbian sites}

A major outcome of this study is that the overall forest structure on pre-Columbian sites is still different from undisturbed forests: a lower aboveground biomass, basal area, and a lower tree density per hectare. Given that our sampled plots were disturbed a long time ago, at least five centuries, this lasting signature of pre-Columbian occupations on the current forest biomass is remarkable. A first hypothesis lies in a very slow recovery of the forest after disturbance by pre-Columbian occupations. From ongoing research, we do know that (1) gently disturbed Amazonian forests (losses of 10$50 \%$ of the initial system biomass) are expected to recover their predisturbance biomass and structure in less than a century (Blanc et al. 2009, Rutishauser et al. 2015, Piponiot et al. 2016, Hiltner et al. 2018) and that (2) secondary forests (losses of $100 \%$ of the initial system biomass) took a median time of $66 \mathrm{yr}$ to recover to $90 \%$ of old-growth values in the neotropics (Poorter et al. 2016). This long-recovery-time first hypothesis is thus very doubtful. A possible alternative hypothesis lies in 


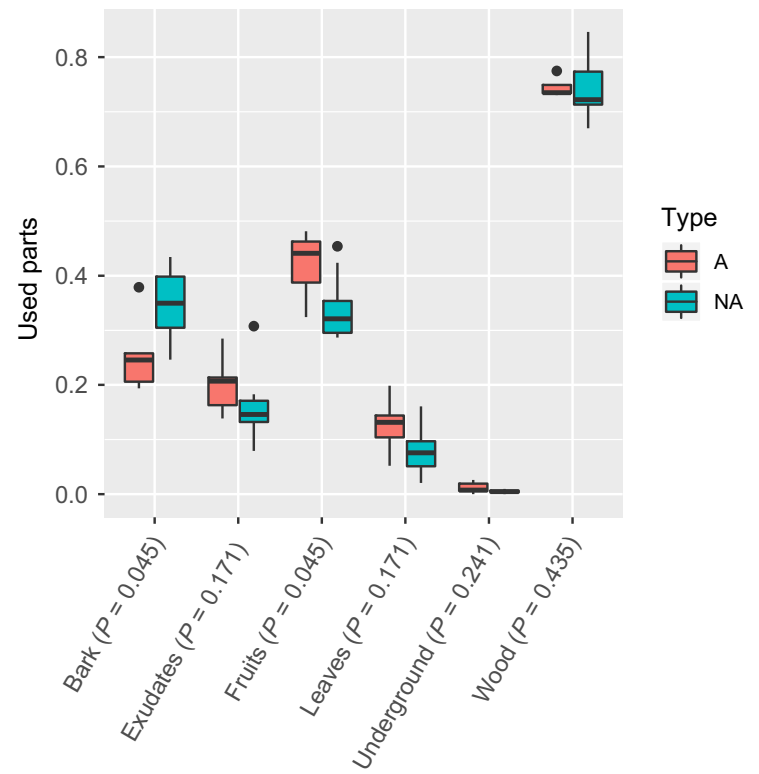

FIG. 7. Comparison of used parts ( $\%$ of trees per plot for which a given part can be used) between anthropized (A) and nonanthropized (NA) plots. $P$ values from Mann-Whitney nonparametric tests.

changes in soil fertility. We do know that (1) pre-Columbian occupancy generally increases the overall soil fertility (Quintero-Vallejo et al. 2015) and that the overall soil fertility directly influences forest structure and dynamics, accelerating tree turnover rates and ultimately diminishing the forest biomass (Quesada et al. 2012). This hypothesis is confirmed by the functional analyses where pre-Columbian sites have more acquisitive tree ecological strategies (lower wood density, lower seed mass, higher specific leaf area, and lower maximal stature; Fig. 4), typical of high-resource-levels environment (Baraloto et al. 2010b, 2012, Sterck et al. 2011). Conversely, nonoccupied plots are dominated by conservative ecological strategies (high wood density, seed mass, maximal stature, and low specific leaf area). A self-maintaining high forest dynamic level mediated by the modified edaphic conditions is thus very likely and has ultimately led to lower current levels of biomass and basal area in pre-Columbian sites. In Europe, Dambrine et al. (2007) also documented a change in understory vegetation composition along a gradient related to $\mathrm{pH}$, available $\mathrm{P}$, and $\delta^{15} \mathrm{~N}$, materializing after human impacts (Roman in the latter case).

\section{Forest composition — significant changes associated with pre-Columbian occupation}

The main gradient of the detected variation in current forest composition in our data set can be attributed to anthropization (Fig. 3), de facto an important, but underestimated, explanatory factor for deciphering floristic patterns in terra firme forests on the Guiana Shield. This result corroborates both observations by Ross (2011), who observed an increase of useful species close to formerly highly occupied Maya settlements in Belize, and the recently published work at the scale of the Amazon basin by Levis et al. (2017). Our finding is of utmost importance for the Guiana Shield, as it is the region where Levis et al. found the lowest correlation, both in terms of abundance and in terms of richness, between domesticated species and archaeological sites. This inconsistency is probably because of the incomplete nature of the archaeological maps of the Guiana Shield. In French Guiana, for example, the archaeological map used by Levis et al. shows an overconcentration of sites in northwestern coastal savannahs. But dozens of ditched sites (including those studied here) have recently been discovered in inner French Guiana, and their number is rapidly increasing with the use of airborne LiDAR. If Levis et al. had had the opportunity to include these new sites in their analyses, their conclusions would likely have been very different. Human influence was, however, not homogeneous, as exemplified by the Aca western plot, which is close to the western NA control Baf on the DCA (Fig. 3), illustrating the influence of the main East-West biogeographical gradient of species composition in the Guiana Shield. Another possible hypothesis might be a different kind of pre-Columbian occupation for the Aca plot (Appendix S2). Archeological elements in this plot suggest an agricultural field, a kind of land use that might have been shorter in time than the other, more perennial, occupations (ditched/ring-ditched sites). Owing to the probably massive effort required to build ditched structures, occupation might have been longer and its influence on forest composition more pervasive. Differences might also be attributed to other cultural traits, given the wide range of cultural manifestations in human societies. Looking in more detail at plant families (Appendix S4: Fig. S1) and indicator species (Appendix S5: Table S1), five families show a clear pattern of association and 15 species appear to be closely associated with As or NAs. Some species found in the literature are closely related to the Guianese species from our plots. Notably, the genera Oenocarpus and Astrocaryum (Balée and Erickson, 2006; Junqueira et al. 2011) are known to be associated with ancient disturbed forests. Because of a relative singularity of the Guiana Shield flora, the 15 indicator species significantly differ from those observed by Junqueira et al. (2011) in the Madeira River drainage, and they might be considered as important indicators for future studies in historical ecology in the region. Moreover, this question of indicator species should be further developed to cover different anthropogenic landscapes, as each type of archaeological site may hold a different composition of indicator species. After Balée (1994), highlighting which species were associated with old fallow in the Ka'apor area, and Clement and colleagues (Clement et al. 2003, Junqueira et al. 2011) for ADE 
areas, it might be interesting to collate all the works at the Amazonian scale to explore their consistency at a larger scale.

\section{Forest diversity-pre-Columbian occupation enhances current beta diversity}

Regarding alpha diversity, our results question the generality of Balée's hypothesis that past human occupation would have elevated species diversity of Amazonian forests (Balée 1994). More specifically, neutral alpha diversities are more difficult to interpret than neutral composition because diversity distributions between As and NAs widely overlap (Appendix S6: Fig. S1). On the contrary, the global trend, even if nonsignificant, for functional alpha diversity seems effectively to be an increase in As compared to NAs. This corroborates our results on functional composition where we found that pre-Columbian occupancy sites are today enriched in acquisitive tree ecological strategies (species with lower wood density, lower seed mass, higher specific leaf area, and lower maximal stature; Fig. 4). The current coexistence of acquisitive and conservative functional strategies automatically increases the functional alpha diversity in anthropized plots, a pattern to be linked to the intermediate disturbance hypothesis (IDH), which states that, locally, maximum alpha diversity should be obtained at intermediate disturbance levels, where diverse ecological strategies may coexist (Molino and Sabatier 2001).

Regarding beta diversity (Fig. 5), the pattern is much clearer than for alpha diversity, with neutral beta diversity significantly increasing with the proportion of anthropized (A) plots in the simulated assemblages. Although the number of species may exhibit the same pattern in A and NA plots, forests shaped by preColumbian societies hold different plant communities (see forest composition chapter above) adapted to different histories of human occupations (Lins et al. 2015). Consequently, beta diversity can increase in landscapes modified by past indigenous societies. Moreover, we may view past indigenous societies as intermediate disturbance agents at the landscape level and, if we admit the validity of the IDH at a regional scale (Guitet et al. 2018), the balanced coexistence of undisturbed and disturbed sites in the landscape should theoretically lead to a maximum beta-diversity level. This hump-shaped beta-diversity theoretical pattern was almost exactly obtained for functional beta diversity and may also explain, for neutral beta diversity, the saturated increase for proportions of As in the simulated assemblages above $50 \%$. Concretely, this means that both highly disturbed and undisturbed landscapes may exhibit lower beta diversity than landscapes with complex and patchy early human occupations. In any case, the presence of pre-Columbian human occupations should be taken into consideration as an additional factor altering current diversity patterns.

\section{Ethnobotanical aspects, another light on pre-Columbian impacts}

Scrutinizing forest composition, the weak predominance of some peculiar families in the disturbed plots (Appendix S4: Fig. S1) as well as the presence of indicator species (Appendix S5: Table S1) can, interestingly, be well explained by ethnobotany. For example, the families most associated with As (Arecaceae, Urticaceae, and Euphorbiaceae) are known, among other things, for their edible fruits (Smith et al. 2007). Nevertheless, discussing at the family level is difficult owing to variation in uses among confamilial species that prohibits a precise analysis. Concerning indicator species, both potential uses and ecological strategies explain a large part of their relevance. Among the most numerous species, Oenocarpus bacaba and Astrocaryum sciophilum are still today esteemed for their edible fruits and probably previously constituted a large part of the diet of pre-Columbian humans (Smith 2015). Seeds of Conceveiba guianensis are also edible, but not used much today. Although its use might explain its abundance in As, its acquisitive ecological strategy is probably more important in shaping its current distribution.

Categories of traditional uses are heterogeneously related to the impact on the resource, and are thus complemented by the category of the plant part used. The more frequent presence of edible species on As (Fig. 6) is accompanied by the increased proportion of species whose seeds and fruits are useful (Fig. 7), and is the most salient result of this study. The 121 edible species censused in our plots, despite the lack of precise data concerning them, probably belong mainly to the semidomesticated or incipiently domesticated categories of Levis et al. (2017), and are often close relatives of some of the 85 edible species censused by these authors, extending their conclusions to the Guiana Shield. Another interesting aspect is the abundance in NAs of species used in construction (Fig. 6). The trend is clear enough to suggest new hypotheses about pre-Columbian impacts on the forest. This observation is nevertheless not confirmed by the "plant parts" category analyses (Fig. 7), which found no selective patterns for plants used for their wood. But species that have useful bark are also closely associated to NAs, giving credit to the idea that using bark on a regular basis is negatively impacting individual demographic performance (but see Amahowe et al. 2018). Conclusions are more difficult to draw for species belonging to the "medicine and magic" and "arts and crafts" categories, which showed no clear pattern. This might be explained by the fact that (1) medicinal uses are of very low impact on plants in general, because of the small quantities gathered, and that (2) crafts species are used in many different ways, some with detrimental effects, some with no or positive impacts. In the same way, the positive and significant correlation between plants used for their leaves and flowers and their abundance in As is probably explained 
by the extremely frequent use of palm leaves in crafts, and it probably mainly reflects the abundance of palms in As because of the concentration of fruits and seeds related to their edibility. Use of underground organs of trees concerns only four species (Socratea exorrhiza, Cecropia obtusa, Tovomita brasiliensis, and Ptychopetalum olacoides), and the observed correlation with As certainly owes more to the acquisitive ecological status and the hyperdominance of both C. obtusa and S. exorrhiza (Ter Steege et al. 2013) than to these uses.

Nevertheless, it is difficult to disentangle human effects (direct or indirect) from geographical and environmental effects without in-depth ecological, soil, and archaeological investigations. The superabundance of acquisitive ecological strategies (mediated by long-lasting soil changes; see the foregoing) might be difficult to tease apart from compositional changes owing to differential ethnobotanical uses.

\section{Conclusion}

This work confirms for the Guiana Shield some trends observed elsewhere in Amazonia regarding the persistent effects of pre-Columbian occupation on modern forests. Our results highlight the change in current forest structure, composition, and diversity between sites formerly occupied and nonoccupied by pre-Columbian populations. By filling a major gap in our knowledge of the Amazonian forests sensu lato (i.e., including the Guiana Shield and other peripheral areas), it helps consider all these socio-ecosystems as directly linked together. PreColumbian presence (1) decreases the current levels of aboveground biomass, basal area, and tree density; (2) is responsible for significant shifts in current species composition with enrichment in species with acquisitive ecological strategies; and (3) strongly enhances the forest beta diversity at landscape scale. Moreover, different uses of tree biodiversity had contrasted impacts on the current vegetation: the edibility of some plants is likely to enhance their association with pre-Columbian sites, similar to the conclusions of Levis et al. (2017). What was expected but never demonstrated before is that preColumbian uses of wood for construction and of bark might also have been detrimental to some species. This approach represents an important step forward in historical ecological studies of Amazonian forests. This demonstrates that, beyond the classic ecological concept of neutral or functional diversity, taking into consideration the utilitarian diversity helps us understand past human influence on these forests. Moreover, a more holistic ethnoecological approach, co-constructed with present-day Amerindian knowledge holders, including their indigenous knowledge related to soil types and fertility, horizontal and vertical forest structure, and general forest functioning in such analyses would be a great step further. Considering the lack of data concerning terra firme archaeology in Amazonia (Stahl 2015, McMichael et al. 2017), our results show that
pre-Columbian influences on Guianan upland forests have not been as discreet and evanescent as previously thought, suggesting that similar studies in other supposedly untouched Amazonian forests, particularly in interfluvial areas, would be of great interest.

\section{AcKNowledgments}

The authors would like to acknowledge the numerous colleagues and students that helped perform ethnobotanical censuses, plot installations, and botanical determinations. Indigenous collaborators whose knowledge was compiled to build the database are warmly thanked. Their input is invaluable. Botanical identifications of trees of the GUYADIV and GUYAFOR plots are based on the collections held in Herbier IRD de Guyane (CAY), and were carried on thanks to the facilities available at this platform. Archaeological map of French Guiana was built thanks to the Patriarche database made available by the Service de l'archéologie of the Direction des affaires culturelles de Guyane (Ministère de la Culture). We would like to thank Doyle McKey for his comments on a preliminary version of this manuscript. This work was supported by "Investissement d'Avenir" grants managed by the Agence Nationale de la Recherche (Labex DRIIHM/IRDHEI and Labex CEBA: ANR-10-LABX-25-01).

\section{Literature Cited}

Ahlbrinck, W. 1931. Encyclopaedie der Karaiben: behelzend taal, zeden en gewoonten dezer indianen. Koninklijke Akademie van Wetenschappen, Amsterdam.

Amahowe, I. O., O. G. Gaoue, A. K. Natta, C. Piponiot, I. C. Zobi, and B. Hérault. 2018. Functional traits partially mediate the effects of chronic anthropogenic disturbance on the growth of a tropical tree. AoB Plants 10:ply036.

Arroyo-Kalin, M. 2010. The Amazonian formative: Crop domestication and anthropogenic soils. Diversity 2:473-504.

Aublet, F. 1775. Histoire des plantes de la Guiane françoise, rangées suivant la méthode sexuell. Didot, London, UK.

Bahuchet, S., F. Grenand, P. Grenand, and de Maret P.. 2000. Les peuples des forêts tropicales aujourd'hui, Vol. 1. Forêts des tropiques, forêts anthropiques: sociodiversité, biodiversité: un guide pratique. APFT-Université libre de Bruxelles, Brussels, Belgium.

Balée, W. 1994. Footprints of the forest: Ka'apor ethnobotany; the historical ecology of plant utilization by an Amazonian people. Columbia University Press, New York, New York, USA; Chichester, UK.

Balée, W. 2013. Cultural forests of the Amazon: a historical ecology of people and their landscapes. University of Alabama Press, Tuscaloosa, Alabama, USA.

Baraloto, C., B. Hérault, C. E. T. Paine, H. Massot, L. Blanc, D. Bonal, J. F. Molino, E. A. Nicolini, and D. Sabatier. 2012. Contrasting taxonomic and functional responses of a tropical tree community to selective logging. Journal of Applied Ecology 49:861-870.

Baraloto, C., C. E. Timothy Paine, S. Patiño, D. Bonal, B. Hérault, and J. Chave. 2010a. Functional trait variation and sampling strategies in species-rich plant communities. Functional Ecology 24:208-216.

Baraloto, C., C. E. Timothy Paine, L. Poorter, J. Beauchene, D. Bonal, A.-M. Domenach, B. Hérault, S. Patiño, J.-C. Roggy, and J. Chave. 2010b. Decoupled leaf and stem economics in rain forest trees. Ecology Letters 13:1338-1347.

Barlow, J., T. A. Gardner, A. C. Lees, L. Parry, and C. A. Peres. 2012. How pristine are tropical forests? An ecological 
perspective on the pre-Columbian human footprint in Amazonia and implications for contemporary conservation. Biological Conservation 151:45-49.

Barthe, S., G. Binelli, B. Hérault, C. Scotti-Saintagne, D. Sabatier, and I. Scotti. 2017. Tropical rainforests that persisted: inferences from the Quaternary demographic history of eight tree species in the Guiana Shield. Molecular Ecology 26:1161-1174

Blanc, L., M. Echard, B. Herault, D. Bonal, E. Marcon, J. Chave, and C. Baraloto. 2009. Dynamics of aboveground carbon stocks in a selectively logged tropical forest. Ecological Applications 19:1397-1404.

Balée, W., and C. Erickson. 2006. Time and complexity in historical ecology: studies in the neotropical lowlands. Columbia University Press, New York, New York.

Bush, M. B., C. H. McMichael, D. R. Piperno, M. R. Silman, J. Barlow, C. A. Peres, M. Power, and M. W. Palace. 2015 Anthropogenic influence on Amazonian forests in pre-history: an ecological perspective. Journal of Biogeography 42:2277-2288.

Chave, J. et al. 2019. Ground data are essential for biomass remote sensing missions. Surveys in Geophysics https://doi. org/10.1007/s10712-019-09528-w.

Chazdon, R. L., and F. G. Coe. 1999. Ethnobotany of woody species in second-growth, old-growth, and selectively logged forests of northeastern Costa Rica. Conservation Biology 13:1312-1322.

Clement, C. R. 1999. 1492 and the loss of Amazonian crop genetic resources. I. The relation between domestication and human population decline. Economic Botany 53:188-202.

Clement, C. R., J. M. McCann, and N. J. H. Smith. 2003. Agrobiodiversity in Amazonia and its relationship with dark earths. Pages 159-178 in J. Lehmann, D. Kern, B. Glaser, and W. I. Woods, editors. Amazonian dark earths: origin, properties, management. Kluwer Academic Publishers, Dordrecht, The Netherlands.

Clement, C. R., W. M. Denevan, M. J. Heckenberger, A. B. Junqueira, E. G. Neves, W. G. Teixeira, and W. I. Woods. 2015 The domestication of Amazonia before European conquest. Proceedings of the Royal Society B 282:20150813.

Dambrine, E., J.-L. Dupouey, L. Laüt, L. Humbert, M. Thinon, T. Beaufils, and H. Richard. 2007. Present forest biodiversity patterns in France related to former Roman agriculture. Ecology 88:1430-1439.

De Caceres, M., P. Legendre, S. K. Wiser, and L. Brotons. 2012. Using species combinations in indicator value analyses. Methods in Ecology and Evolution 3:973-982.

Dufrêne, M., and P. Legendre. 1997. Species assemblages and indicator species: the need for a flexible asymmetrical approach. Ecological Monographs 67:345-366.

Erickson, C. L. 2000. Lomas de ocupación en los Llanos de Moxos. Page 207-226 in A. D. Coiroloand and R. B. Boksar, editors, La Arqueologia de Tierras Bajas, Comision Nacional de Arqueologia, Montevideo, Uruguay.

Fargeon, H., M. Aubry-Kientz, O. Brunaux, L. Descroix, R. Gaspard, S. Guitet, V. Rossi, and B. Hérault. 2016. Vulnerability of commercial tree species to water stress in logged forests of the Guiana Shield. Forests 7:105.

Flores, O., B. Hérault, M. Delcamp, É. Garnier, and S. GourletFleury. 2014. Functional traits help predict post-disturbance demography of tropical trees. PLoS ONE 9:e105022.

Grau, O., J. Peñuelas, B. Ferry, V. Freycon, L. Blanc, M. Desprez, C. Baraloto, J. Chave, L. Descroix, and A. Dourdain. 2017. Nutrient-cycling mechanisms other than the direct absorption from soil may control forest structure and dynamics in poor Amazonian soils. Scientific Reports 7:45017.
Grenand, P. 1980. Introduction à l'étude de l'univers Wayapi: ethnoécologie des Indiens du Haut-Oyapock (Guyane Française), Langues et Civilisations à Tradition Orale. SELAF, Paris, France.

Grenand, P. 1992. The use and cultural significance of the secondary forest among the Wayapi Indians. Pages 27-40 in M. Plotkin and L. Famolare (dir.). Sustainable harvest and marketing of rain forest products. Island Press, Washington, D.C., USA.

Grenand, P., C. Moretti, H. Jacquemin, and M.-F. Prévost. 2004. Pharmacopées traditionnelles en Guyane: Créoles, Palikur, Wayãpi. IRD Orstom, Paris, France.

Guitet, S., D. Sabatier, O. Brunaux, P. Couteron, T. Denis, V. Freycon, S. Gonzalez, B. Hérault, G. Jaouen, and J.-F. Molino. 2018. Disturbance regimes drive the diversity of regional floristic pools across Guianan rainforest landscapes. Scientific Reports 8:3872.

Heckenberger, M. J., A. Kuikuro, U. T. Kuikuro, J. C. Russell, M. Schmidt, C. Fausto, and B. Franchetto. 2003. Amazonia 1492: pristine forest or cultural parkland? Science 301:1710 1714.

Heckenberger, M. J., J. C. Russell, J. R. Toney, and M. J. Schmidt. 2007. The legacy of cultural landscapes in the Brazilian Amazon: implications for biodiversity. Philosophical Transactions of the Royal Society B 362:197-208.

Heckenberger, M. J., J. C. Russell, C. Fausto, J. R. Toney, M. J. Schmidt, E. Pereira, B. Franchetto, and A. Kuikuro. 2008. Pre-Columbian urbanism, anthropogenic landscapes, and the future of the Amazon. Science 321:1214-1217.

Hérault, B. 2007. Reconciling niche and neutrality through the Emergent Group approach. Perspectives in Plant Ecology, Evolution and Systematics 9:71-78.

Hérault, B., B. Bachelot, L. Poorter, V. Rossi, F. Bongers, J. Chave, C. T. Paine, F. Wagner, and C. Baraloto. 2011. Functional traits shape ontogenetic growth trajectories of rain forest tree species. Journal of Ecology 99:1431-1440.

Hérault, B., and O. Honnay. 2007. Using life-history traits to achieve a functional classification of habitats. Applied Vegetation Science 10:73-80.

Hérault, B., J. Ouallet, L. Blanc, F. Wagner, and C. Baraloto. 2010. Growth responses of Neotropical trees to logging gaps. Journal of Applied Ecology 47:821-831.

Hérault, B., and C. Piponiot. 2018. Key drivers of ecosystem recovery after disturbance in a Neotropical forest: long-term lessons from the Paracou experiment, French Guiana. Forest Ecosystems 5:2.

Hiltner, U., A. Huth, A. Bräuning, B. Hérault, and R. Fischer. 2018. Simulation of succession in a Neotropical forest: High selective logging intensities prolong the recovery times of ecosystem functions. Forest Ecology and Management 430:517-525.

Hogan, J. A., B. Hérault, B. Bachelot, A. Gorel, M. Jounieaux, and C. Baraloto. 2018. Understanding the recruitment response of juvenile Neotropical trees to logging intensity using functional traits. Ecological Applications 28:19982010.

Junqueira, A. B., G. H. Shepard, Jr., and C. R. Clement. 2011. Secondary forests on anthropogenic soils of the middle Madeira River: valuation, local knowledge, and landscape domestication in Brazilian Amazonia. Economic Botany 65:85-99.

Kloos, P. 1971. The Maroni River Caribs. Van Gorcum, Amsterdam, The Netherlands.

Levis, C., P. F. de Souza, J. Schietti, T. Emilio, J. L. P. da. V. Pinto, C. R. Clement, and F. R. C. Costa. 2012. Historical human footprint on modern tree species composition in the 
Purus-Madeira Interfluve, Central Amazonia. PLoS ONE 7: e48559.

Levis, C. et al. 2017. Persistent effects of pre-Columbian plant domestication on Amazonian forest composition. Science 355:925-931.

Lins, J., H. P. Lima, F. B. Baccaro, V. F. Kinupp, G. H. Shepard, Jr., and C. R. Clement. 2015. Pre-Columbian floristic legacies in modern homegardens of Central Amazonia. PLoS ONE 10:e0127067.

Marcon, E., and B. Herault. 2015a. Decomposing phylodiversity. Methods in Ecology and Evolution 6:333-339.

Marcon, E., and B. Hérault. 2015b. entropart: An R package to measure and partition diversity. Journal of Statistical Software https://doi.org/10.18637/jss.v067.i08

McKey, D., S. Rostain, J. Iriarte, B. Glaser, J. J. Birk, I. Holst, and D. Renard. 2010. Pre-Columbian agricultural landscapes, ecosystem engineers, and self-organized patchiness in Amazonia. Proceedings of the National Academy of Sciences 107:7823-7828.

McMichael, C. H., D. R. Piperno, E. G. Neves, M. B. Bush, F. O. Almeida, G. Mongeló, and M. B. Eyjolfsdottir. 2015. Phytolith assemblages along a gradient of ancient human disturbance in Western Amazonia. Frontiers in Ecology and Evolution https://doi.org/10.3389/fevo.2015.00141

McMichael, C. N., F. Matthews-Bird, W. Farfan-Rios, and K. J. Feeley. 2017. Ancient human disturbances may be skewing our understanding of Amazonian forests. Proceedings of the National Academy of Sciences 114:522-527.

Mestre, M. 2013. Yaou. Rapport de diagnostic archéologique. Inrap Grand Sud-Ouest et Dom, Cayenne, French Guiana

Mestre, M., M. Hildebrand, and P. Texier. 2008. Un exemple d'utilisation du lidar sous couvert forestier guyanais. Archéopages 23:69-75.

Molino, J. F., and D. Sabatier. 2001. Tree diversity in tropical rain forests: a validation of the intermediate disturbance hypothesis. Science 294:1702-1704.

Ogeron, C., G. Odonne, A. Cristinoi, J. Engel, P. Grenand, J. Beauchêne, B. Clair, and D. Davy. 2018. Palikur traditional roundwood construction in eastern French Guiana: ethnobotanical and cultural perspectives. Journal of Ethnobiology and Ethnomedicine 14:28.

Office National des Forêts (ONF). 2004. Guide de reconnaissance des arbres de Guyane. Office national des forêts, [Fontainebleau], France.

Oksanen, J., F. G. Blanchet, R. Kindt, P. Legendre, P. R. Minchin, R. B. O'Hara, G. L. Simpson, P. Solymos, M. H. H. Stevens, and H. Wagner. 2015. vegan: community ecology package. Package version 2.3-0. http://CRAN.R-project.org/ package $=$ vegan

Piponiot, C., G. Derroire, L. Descroix, L. Mazzei, E. Rutishauser, P. Sist, and B. Hérault. 2018. Assessing timber volume recovery after disturbance in tropical forests-A new modelling framework. Ecological Modelling 384:353-369.

Piperno, D. R., C. McMichael, and M. B. Bush. 2015. Amazonia and the Anthropocene: What was the spatial extent and intensity of human landscape modification in the Amazon Basin at the end of prehistory? Holocene 25:1588-1597.

Piperno, D. R., C. McMichael, and M. B. Bush. 2017. Further evidence for localized, short-term anthropogenic forest alterations across pre-Columbian Amazonia. Proceedings of the National Academy of Sciences 114:E4118-E4119.

Piponiot, C. et al. 2016. Carbon recovery dynamics following disturbance by selective logging in Amazonian forests. eLife. https://doi.org/10.7554/elife. 21394

Piponiot, C. et al. 2019. Can timber provision from Amazonian production forests be sustainable? Environmental Research Letters 14:064014.
Poorter, L. et al. 2016. Biomass resilience of Neotropical secondary forests. Nature 530:211.

Prance, G. T., W. Balée, B. M. Boom, and R. L. Carneiro. 1987. Quantitative ethnobotany and the case for conservation in Amazonia. Conservation Biology 1:296-310.

Quesada, C. A., O. L. Phillips, M. Schwarz, C. I. Czimczik, T. R. Baker, S. Patiño, N. M. Fyllas, M. G. Hodnett, R. Herrera, and S. Almeida. 2012. Basin-wide variations in Amazon forest structure and function are mediated by both soils and climate. Biogeosciences 9:2203-2246.

Quintero-Vallejo, E., Y. Klomberg, F. Bongers, L. Poorter, M. Toledo, and M. Peña-Claros. 2015. Amazonian dark earth shapes the understory plant community in a Bolivian forest. Biotropica 47:152-161.

Réjou-Méchain, M., A. Tanguy, C. Piponiot, J. Chave, and B. Hérault. 2017. biomass: an R package for estimating aboveground biomass and its uncertainty in tropical forests. Methods in Ecology and Evolution 8:1163-1167.

Ross, N. J. 2011. Modern tree species composition reflects ancient Maya "forest gardens" in northwest Belize. Ecological Applications 21:75-84.

Rostain, S. 2008. The archaeology of the Guianas: an overview. Pages 279-302 in H. Silverman and W. H. Isbell, editors. The handbook of South American archaeology. Springer, New York, New York, USA.

Rostain, S. 2010. Pre-Columbian earthworks in coastal Amazonia. Diversity 2:331-352.

Rostain, S. 2012. Islands in the rainforest: Landscape management in pre-Columbian Amazonia. Left Coast Press, New York, New York.

Rutishauser, E. et al. 2015. Rapid tree carbon stock recovery in managed Amazonian forests. Current Biology 25:R787-R788.

Sabatier, D., M. Grimaldi, M.-F. Prévost, J. Guillaume, M. Godron, M. Dosso, and P. Curmi. 1997. The influence of soil cover organization on the floristic and structural heterogeneity of a Guianan rain forest. Plant Ecology 131:81-108.

Saunaluoma, S., and D. Schaan. 2012. Monumentality in Western Amazonian formative societies: geometric ditched enclosures in the Brazilian state of Acre. Antiqua 2:1.

Schaan, D. P. 2011. Sacred geographies of ancient Amazonia: Historical ecology of social complexity. Left Coast Press, New York, New York.

Schmidt, M. J. 2010. Reconstructing tropical nature: Prehistoric and modern anthrosols (terra preta) in the Amazon rainforest, upper Xingu River, Brazil. University of Florida, Gainesville, Florida, USA.

Schmidt, M. J., and M. J. Heckenberger. 2009. Amerindian anthrosols: Amazonian dark earth formation in the Upper Xingu. Pages 163-191 in W. I. Woods, W. G. Teixeira, J. Lehmann, C. Steiner, A. WinklerPrins, and L. Rebellato, editors. Amazonian dark earths: Wim Sombroek's vision. Springer, Berlin, Germany.

Shepard, G. H., Jr., and H. Ramirez. 2011. "Made in Brazil": human dispersal of the Brazil nut (Bertholletia excelsa, Lecythidaceae) in Ancient Amazonia. Economic Botany 65:44-65.

Smith, N. 1980. Anthrosols and human carrying capacity in Amazonia. Annals of the Association of American Geographers 70:553-566.

Smith, N. 2015. Palms and people in the Amazon. Springer International Publishing AG, Berlin, Germany.

Smith, N., R. Vásquez, and W. H. Wust. 2007. Amazon River fruits: flavours for conservation. Missouri Botanical Garden Press, Saint Louis, Missouri, USA.

Sombroek, W. G. 1966. Amazon soils. Centre for Agricultural Publications and Documentation, Wageningen, The Netherlands. 
Souza, J. G. et al. 2018. Pre-Columbian earth-builders settled along the entire southern rim of the Amazon. Nature Communications 9:1125.

Stahl, P. W. 2015. Interpreting interfluvial landscape transformations in the pre-Columbian Amazon. Holocene 25:1598 1603.

Sterck, F., L. Markesteijn, F. Schieving, and L. Poorter. 2011 Functional traits determine trade-offs and niches in a tropical forest community. Proceedings of the National Academy of Sciences 108:20627-20632.

Ter Steege, H., N. C. Pitman, D. Sabatier, C. Baraloto, R. P. Salomão, J. E. Guevara, O. L. Phillips, C. V. Castilho, W. E. Magnusson, and J.-F. Molino. 2013. Hyperdominance in the Amazonian tree flora. Science 342:1243092. van Andel, T. 2000. Non-timber forest products of the NorthWest district of Guyana. Tropenbos-Guyana Programme, Utrecht, The Netherlands.

Watling, J., J. Iriarte, F. E. Mayle, D. Schaan, L. C. R. Pessenda, N. J. Loader, F. A. Street-Perrott, R. E. Dickau, A. Damasceno, and A. Ranzi. 2017a. Impact of pre-Columbian "geoglyph" builders on Amazonian forests. Proceedings of the National Academy of Sciences 114:1868-1873.

Watling, J., J. Iriarte, F. E. Mayle, D. Schaan, L. C. R. Pessenda, N. J. Loader, F. A. Street-Perrott, R. E. Dickau, A. Damasceno, and A. Ranzi. 2017b. Reply to Piperno et al.: It is too soon to argue for localized, short-term human impacts in interfluvial Amazonia. Proceedings of the National Academy of Sciences 114:E4120-E4121.

\section{SUPPORTING INFORMATION}

Additional supporting information may be found in the online version of this article at http://onlinelibrary.wiley.com/doi/ 10.1002/ecy.2806/suppinfo

\section{Data Availability}

Data are available from the Dryad Digital Repository: https://doi.org/10.5061/dryad.4h75q1p. 